\title{
Earthquake rocks Pacific Northwest libraries
}

Libraries throughout the Pacific Northwest are recovering from the region's most powerful earthquake in more than 50 years. On February 28, books were thrown and shelving units pulled loose during a quake registering 6.8 on the Richter scale. Due to the quake's epicenter being 30 miles underground, library damage was minimal and no injuries were reported. Seismic retrofitting precautions and library emergency planning also served to limit earthquake damage to buildings and prevent injuries.

Hours after the 10:55 a.m. quake, our region's librarians were sending messages to colleagues on the status of their libraries. Portland State University's (Oregon)

Web site (http://www.lib. pdx.edu/old/staffsocial/ earthquake/feb2801.

html) displayed photos of books piled in their library aisles and damage to a microfiche cabinet.

Bill Bruner, library services dean at Evergreen State College Library (Olympia, Washington), reported that half their collection was on the floor, in addition to damaged light fixtures, downed ceiling tiles, and minor water damage to their slide collection and media labs. Bruner expected it would take weeks to re-shelve materials. Staff from neighboring O'Grady Library at St. Martin's College (Lacey, Washington) will help restore order, as director Dalia Hagan reported that their new library came through the quake

Designed by architectural firms WellesPugsley and Leo A. Daly, the library received funding from the state of Nevada and the Lied Foundation Trust. The library features:

- a \$1.5 million automated storage and retrieval system capable of holding 1.2 million volumes. They system's crane with "flying colors." Recent renovation at the University of Puget Sound Library (Tacoma, Washington) spared that library damage, said library' director Marilyn Mitchell. Mortvedt Library at Pacific Lutheran University also reported no damage, thanks in part to the rocky soil of their Tacoma location.

In the Seattle area, Charles Diede, library director of the DV Hurst Library at Northwest College (Kirkland, Washington), estimated displacement of 10 percent of their collection and the need to repair wall-anchored shelving units. John Popko at Seattle University's Lemieux Library reported that several thousand of their books and periodicals were on the floor, and one shelving unit was detached.

Library staff responded during the quake to ensure patron safety. Bob Menanteaux of the Seattle University Law Library had a har- rowing experience. As students on the fourth floor ran for a glass staircase during the quake, he ordered them under tables to avoid being hit by flying books, if not more. Menanteaux described windows as billowing "in and out like bed sheets hung out to dry." Concerned about aftershocks once the shaking ceased, he ushered students through fire exits. He estimated that 60,000 to 70,000 volumes were thrown from shelves. Fortunately, original stack diagrams from their 1999 move to a new building will speed an expected four-week re-shelving project.Francesca Lane Rasmus, Pacific Lutheran University,lanerafr@plu.edu

and robotic arm is visible through a glass wall. Patrons can request items electronically and the retrieval system will automatically deliver available items to a pick-up area;

- an Information Commons with 96 computer workstations, remote laptop 